\title{
Managed Aquifer Recharge in Africa: Taking Stock and Looking Forward
}

\author{
Girma Y Ebrahim ${ }^{1, *}$, Jonathan F. Lautze ${ }^{2}$ and Karen G. Villholth ${ }^{2}$ \\ 1 International Water Management Institute, P.O. Box 5689, Addis Ababa, Ethiopia \\ 2 International Water Management Institute, Private Bag X813, Silverton, Pretoria 0127, South Africa; \\ J.Lautze@cgiar.org (J.F.L.); K.Villholth@cgiar.org (K.G.V.) \\ * Correspondence: g.ebrahim@cgiar.org
}

Received: 20 November 2019; Accepted: 8 June 2020; Published: 27 June 2020

\begin{abstract}
Climatic variability and change result in unreliable and uncertain water availability and contribute to water insecurity in Africa, particularly in arid and semi-arid areas and where water storage infrastructure is limited. Managed aquifer recharge (MAR), which comprises purposeful recharge and storage of surface runoff and treated wastewater in aquifers, serves various purposes, of which a prominent one is to provide a means to mitigate adverse impact of climate variability. Despite clear scope for this technology in Africa, the prevalence and range of MAR experiences in Africa have not been extensively examined. The objective of this article is provide an overview of MAR progress in Africa and to inform the potential for future use of this approach in the continent. Information on MAR from 52 cases in Africa listed in the Global MAR Portal and collated from relevant literature was analyzed. Cases were classified according to 13 key characteristics including objective of the MAR project, technology applied, biophysical conditions, and technical and management challenges. Results of the review indicate that: (i) the extent of MAR practice in Africa is relatively limited, (ii) the main objective of MAR in Africa is to secure and augment water supply and balance variability in supply and demand, (iii) the surface spreading/infiltration method is the most common MAR method, (iv) surface water is the main water source for MAR, and (v) the total annual recharge volume is about $158 \mathrm{Mm}^{3} /$ year. MAR schemes exist in both urban and rural Africa, which exemplify the advancement of MAR implementation as well as its out scaling potential. Further, MAR schemes are most commonly found in areas of high inter-annual variability in water availability. If properly planned, implemented, managed, maintained and adapted to local conditions, MAR has large potential in securing water and increasing resilience in Africa. Ultimately, realizing the full potential of MAR in Africa will require undertaking hydrogeological and hydrological studies to determine feasibility of MAR, especially in geographic regions of high inter-annual climate variability and growing water demand. This, supported by increased research to gauge success of existing MAR projects and to address challenges, would help with future siting, design and implementation of MAR in Africa.
\end{abstract}

Keywords: managed aquifer recharge; water security; climate change; Africa

\section{Introduction}

Challenges posed by climate variability and change in Africa are widely recognized [1]. Sadoff et al. [2] highlight how rainfall variability disrupts productivity of rain-fed agriculture, contributes to disasters associated with floods and droughts, and stalls economic growth. An African Ministers' Council on Water (AMCOW) report [3] state that recurrent droughts in sub-Saharan Africa are a dominant climate risk that compromises livelihoods, water and food security and exerts a major negative effect on Gross Domestic Product (GDP) growth in one third of the continent's countries. 
Groundwater currently contributes water supply to increasing populations in Africa, while also presenting a resource with significant potential for further development for multiple uses in parts of the continent [4]. Particularly in arid and rural areas, groundwater plays a key role in enhancing resilience. However, with increasing climate variability, frequency of extreme events, and population growth, water development in Africa needs to go forward in ways that consider all water sources in conjunction to enhance sustainable, reliable, climate-smart and equitable water availability and access [5].

Managed aquifer recharge (MAR) is a water management option that provides a means of intentionally recharging and storing water underground for subsequent recovery and beneficial use. It provides an important buffer against the impacts of climate variability and change, especially when additional water is recharged during wet or flooding periods for subsequent abstraction during dry or drought periods [6]. MAR has been identified to hold particular potential in arid and semi-arid areas where the control and storage of increasingly irregular surface runoff is challenging [7]. According to Tuinhof et al. [8], MAR is a significant adaptation option for coping with climate change and hydrological variability. Importantly, MAR provides water storage that is generally better protected against loss from evaporation $[9,10]$. MAR may take advantage of sources other than surface water runoff, e.g., by using treated wastewater, which often provides a more reliable source, while requiring stricter control of water quality [11].

Despite the large scope for MAR in Africa, there has been scant effort to take stock of MAR implementation and experience in the continent and to assess further potential with the exception of project report by Ebrahim et al. [12]. Dillon et al. [13] provided an overview of MAR in the Southern Africa, while Murray [14] provided an introductory guide to MAR in the Southern African Development Community (SADC) for the Groundwater Management Institute (SADC-GMI) and assessed the MAR case in the city of Windhoek, Namibia [15]. Similarly, Bugan et al. [16] and Jovanovic et al. [17] examined the Atlantis MAR scheme in South Africa [18]. Previous regional syntheses have also been undertaken in Europe [19] and Latin America and the Caribbean [20]. Recently, the research group 'Innovative Web-Based Decision Support System for Water Sustainability under a Changing Climate' (INOWAS) and the International Groundwater Resources Assessment Centre (IGRAC) produced the first global inventory of MAR sites. It contains key information and parameters related to implementation and bio-physical conditions of about 1200 MAR schemes in 62 countries worldwide [21]. No work has specifically synthesized past MAR experience in Africa.

As such, the objective of this article is to compile and synthesize experience on MAR across Africa from documented schemes in order to inform the feasibility and modalities of future MAR implementation in the continent.

\section{Methods}

\subsection{Case Collation}

Collation of cases for this article is primarily based on a review of the Global MAR Portal [22]. Case information in the portal generally includes country, site name, coordinates, MAR type, MAR key objective, operation start year, source of water, and final use. The portal contains 44 cases from Africa. Furthermore, a literature search was undertaken to expand the database with additional cases, as well as obtain Supplementary Information on existing cases. Eight additional cases were identified through this literature search. Hence, in total 52 cases were reviewed. All the cases were originally compiled from sources including: technical governmental documents (35\%), peer reviewed publications (28\%), conference presentations and proceedings (22\%) and Master of Science theses (15\%). The compiled set of MAR cases likely does not reflect a complete inventory of MAR practice in Africa, as documentation is sometimes contained in less easily accessible technical governmental reports (e.g., Wipplinger [23]) or in non-English language (e.g., French, Portuguese, and Arabic), which were not considered in this analysis (experts from non-English speaking countries were consulted to inquire about additional 
cases). For example, Gijsbertsen and Groen [24] reported that in the Kitui District in Kenya, more than 500 sand dams were constructed since 1994 by collaboration of a Non-Governmental Organization (NGO) called SASOL (Sahelian Solution Foundation) and local communities. However, only eight sand dam cases in Kenya are found in the Global MAR Portal and included in this article. Still, the database applied represents the current best available dataset. It is assumed that the cases included in the analysis are representative of the types of existing MAR in Africa. Both full scale operation and pilot cases were considered (Annex S1 of the Electronic Supplementary Material (ESM) specify which schemes belong to full scale and pilot scale). The focus of this review is on single MAR schemes with individual documentation, disregarding landscape type approaches to enhancing recharge.

\subsection{Case Classification}

Classification of MAR cases for this study was based on various scheme characteristics (Table 1) and derived from the classification in the Global MAR Portal [22] and additional sources. In total, 13 parameters were used for classification. Some parameters, related to the biophysical and environmental conditions at the MAR sites, were determined from separate sources, e.g., rainfall, inter-annual variability of water availability, soil type, and geology (Table 1). Other factors, related to socio-economics, costs (capital and operational) and detailed water quality aspects, are important, but scarcity of information on these parameters precluded their inclusion in the analytical framework.

Table 1. Managed aquifer recharge (MAR) classification framework.

\begin{tabular}{clc}
\hline Parameter & \multicolumn{1}{c}{ Explanation } & Source \\
\hline Location & Country and geographic coordinates & {$[13,22,25-30]$} \\
\hline Start year & Year in which MAR scheme was put in operation & {$[13,22,25-30]$} \\
Main MAR type & $\begin{array}{l}\text { Surface spreading/infiltration; open well, shaft and borehole } \\
\text { injection; in-channel modification; rainwater and runoff } \\
\text { harvesting and induced bank filtration }\end{array}$ & {$[13,22,25-30]$} \\
\hline \multirow{2}{*}{ Source of water } & $\begin{array}{l}\text { River water, treated wastewater, multiple sources (e.g., river } \\
\text { water and treated wastewater, stormwater runoff and treated } \\
\text { wastewater), groundwater, and rooftop runoff }\end{array}$ & {$[13,22,25-30]$} \\
\hline
\end{tabular}

(a) to secure and augment water supply (balance variation in water supply and demand)

(b) to improve water quality

(c) to ameliorate groundwater level decline

(d) to prevent seawater intrusion

Key MAR objective

(e) to secure water supply in drought and

Reviewed cases emergency situations

(f) to both augment water supply and prevent seawater intrusion

(g) to enhance environmental flow

\begin{tabular}{clcc}
\hline Recharge volume & Volume of water recharged through MAR per year & Reviewed cases \\
\hline Final use (sector) & $\begin{array}{l}\text { Domestic water supply, agricultural use, industrial use, } \\
\text { environmental use }\end{array}$ & {$[13,22,25-30]$} \\
\hline Challenges & $\begin{array}{l}\text { Challenges related to technical, bio-physical, and managerial } \\
\text { issues e.g., site selection and design, operation and maintenance }\end{array}$ & Reviewed cases \\
\hline Rainfall & Long-term average annual rainfall in the area of the MAR site & [31] \\
\hline $\begin{array}{c}\text { Inter-annual variability } \\
\text { of water availability }\end{array}$ & $\begin{array}{l}\text { Calculated as the standard deviation of available "blue" water } \\
\text { divided by the mean. The available "blue" water approximates } \\
\text { naturalized river discharge. It is an estimate of surface water } \\
\text { availability after deducting water consumed upstream. }\end{array}$ & [32,33] \\
\hline $\begin{array}{c}\text { Location in } \\
\text { transboundary aquifer }\end{array}$ & $\begin{array}{l}\text { Whether the MAR scheme is located in an identified } \\
\text { transboundary aquifer or not }\end{array}$ \\
\hline Geology & $\begin{array}{l}\text { Geology determined from global geology map and classified } \\
\text { into two major rock types: sedimentary and hard rocks }\end{array}$ & [34]
\end{tabular}


Information on MAR schemes in Table 1 was mostly obtained from the Global MAR Portal, and missing information was obtained from the literature. Likewise, recharge volume, key MAR objective and challenges in MAR implementation were obtained through additional literature review. The key MAR objective classification adopted in this study are more specific than the three main MAR objective classes of the Global MAR portal; (i.e., maximizing natural storage, maximizing natural storage and physical aquifer management, and water quality improvement). Challenges reported associated with MAR applications are broad and may include technical, biophysical, managerial, socio-economic, regulatory, institutional issues, availability of MAR water, water quality and degradation, etc. These were broadly divided into challenges in site selection and design on the one hand, and challenges in operation and maintenance on the other.

Four biophysical parameters were considered. First, long-term average annual rainfall was determined for the 52 cases. Data were extracted from the Climate Hazards Group Infrared Precipitation with Stations version 2 (CHIRPS) [31]. CHIRPS combines $0.05^{\circ} \times 0.05^{\circ}$ resolution satellite imagery with in-situ station measurements. CHIRPS data are available from 1981-present (ftp://ftp.chg.ucsb. edu/pub/org/chg/products/CHIRPS-2.0).

Second, inter-annual variability of water availability were determined using geospatial data from Aqueduct Global Maps 2.1 [33]. Inter-annual variability of water availability is calculated as the standard deviation of the annual available "blue" water divided by the mean of annual available "blue" water (1950-2010). Water availability here is defined as the surface water available after accounting for sanctioned diversions upstream. Hence, "blue" water hereafter is referred to as surface water.

A third biophysical parameter considered was whether the aquifer or aquifer system for a particular MAR scheme is transboundary, i.e., whether the aquifer traverses a national border, as defined from present delineation or not. A map of the transboundary aquifers of the world [34] was used to classify the aquifers. MAR implementation in a transboundary aquifer might be a coincidence rather than planned.

Finally, the fourth biophysical parameter, surficial geology of the MAR sites, was classified using the Global Lithological Map (GLiM) developed by Hartmann and Moosdorf [35], which has an average resolution of 1:3,750,000 and consists of 16 lithological classes. These were lumped into two major rock types for the purpose of this study: sedimentary and hard rock (The geology represents the general surficial geology of the MAR sites. Whether this is also representing the actual geologic formation used to store MAR recharge, which could be the case for many sites, has not been assessed).

It should be noted that additional MAR site information, such as soil infiltration rates, unsaturated zone thickness, and aquifer hydraulic conductivities/transmissivity, were obtainable for a few cases from the literature review. However, these classifications are not included in the present study due to limited data. Detailed data sets of parameters in Table 1 for the MAR cases are provided in Annex S1 (MAR scheme information) and Annex S2 (MAR site information) of the ESM.

\section{Results}

The MAR cases are concentrated in nine countries in Africa. The vast majority of African countries have not implemented MAR. MAR is practiced in greatest abundance in South Africa with 17 reported cases, followed by Tunisia with 11 cases, Kenya with eight cases, and Algeria with five cases (Figure 1). Five additional countries also present evidence of MAR implementation (Egypt, Ethiopia, Morocco, Namibia and Nigeria), with up to four cases per country. It appears that MAR is more often practiced in Africa's wealthier, yet drier countries or where a certain MAR technology has gained popularity (like sand dams in Kenya, see below). 


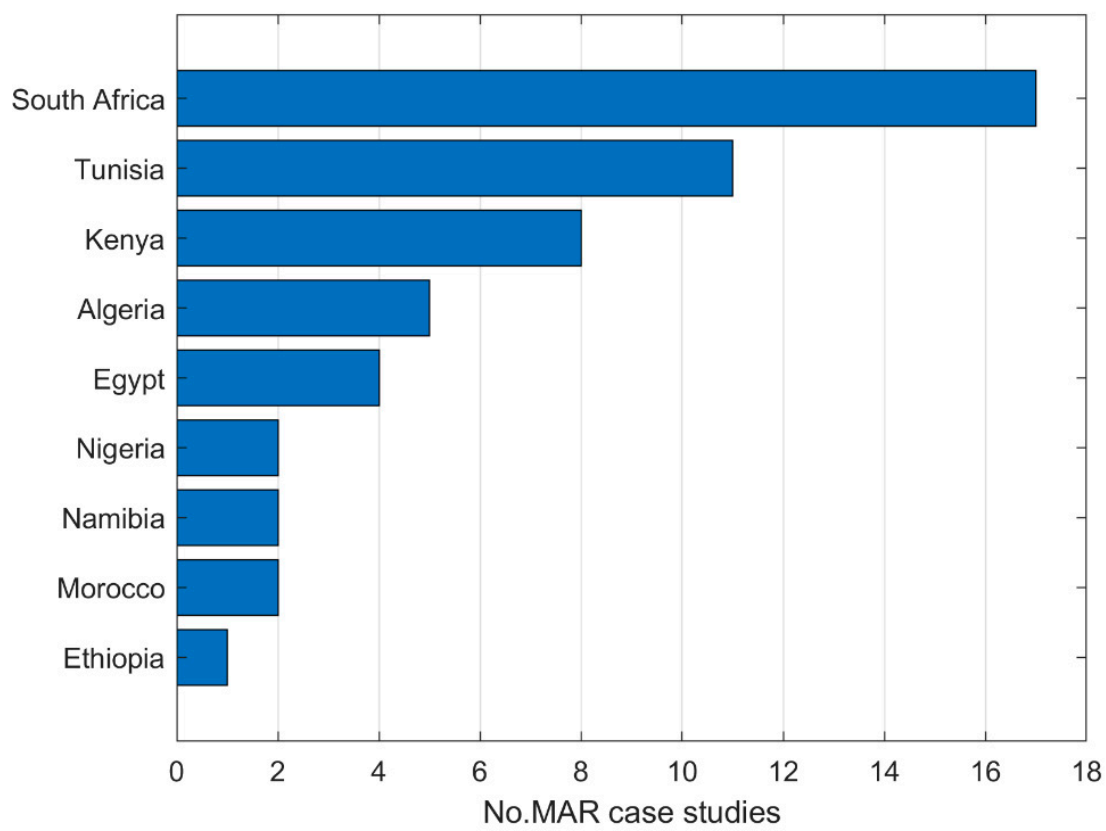

Figure 1. Number of MAR cases in Africa per country $(n=52)$.

The main MAR type is the surface spreading/infiltration method. The most common MAR type is the surface spreading/infiltration method, the second most common is open well, shaft and borehole injection, and the third is in-channel modification (Figure 2). In-channel-modification using sand dams is the most practiced MAR type in Kenya, while in Tunisia, it is the spreading/infiltration method, and in South Africa, the open well, shaft and borehole injection method (Table 2). The Sidfa Riverbank Filtration case in Egypt [36] is the only reported induced river bank filtration case in Africa. There are no reported cases of rainwater and runoff harvesting.

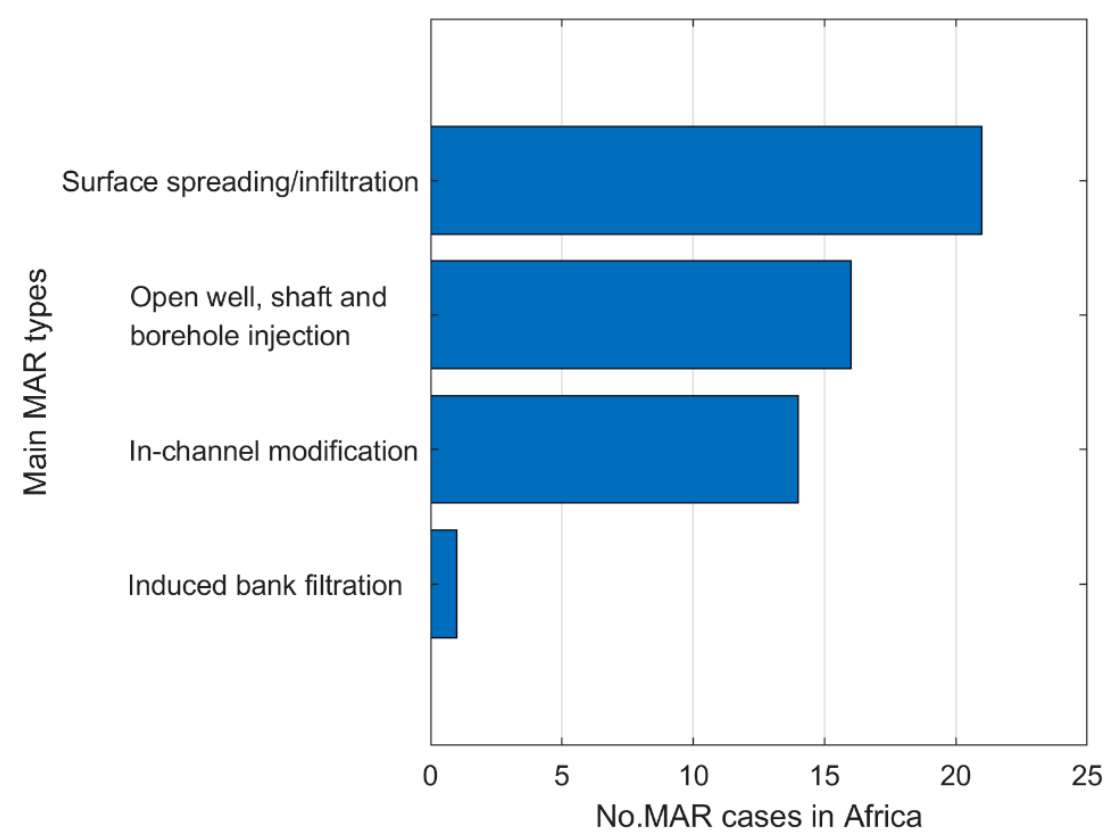

Figure 2. Number of MAR cases in Africa per main MAR type $(n=52)$. 
Table 2. Number of main MAR types per country.

\begin{tabular}{ccccc}
\hline Country & $\begin{array}{c}\text { Surface } \\
\text { Spreading/Infiltration }\end{array}$ & $\begin{array}{c}\text { Open Well, Shaft } \\
\text { and Borehole } \\
\text { Injection }\end{array}$ & $\begin{array}{c}\text { In-Channel } \\
\text { Modification }\end{array}$ & $\begin{array}{c}\text { Induced Bank } \\
\text { Filtration }\end{array}$ \\
\hline Algeria & 5 & - & & \\
Egypt & 3 & - & 1 & - \\
Ethiopia & - & - & 8 & - \\
Kenya & - & - & 1 & - \\
Morocco & 1 & 1 & & - \\
Namibia & 1 & 1 & 1 & - \\
Nigeria & 1 & 12 & 3 & - \\
South Africa & 4 & 2 & 14 & 1 \\
Tunisia & 6 & 16 & & - \\
Total & 21 & & - & - \\
\hline
\end{tabular}

Implementation of MAR started in the 1960s and has increased over time. The first MAR projects in Africa were launched in 1965, in Soukra, Tunisia [29] and Polokwane, South Africa [13], two followed in the 1970s, and three in the 1980s. The pace of MAR implementation increased substantially in the 1990s with seven new projects undertaken, 16 more projects in the 2000s, and seven projects in the 2010s (Figure 3). One particular example of MAR proliferation is sand dam implementation in Kenya in the 2000s. The apparently illogical decline in the number of MAR cases in the 2010s could be due to lag in reporting.

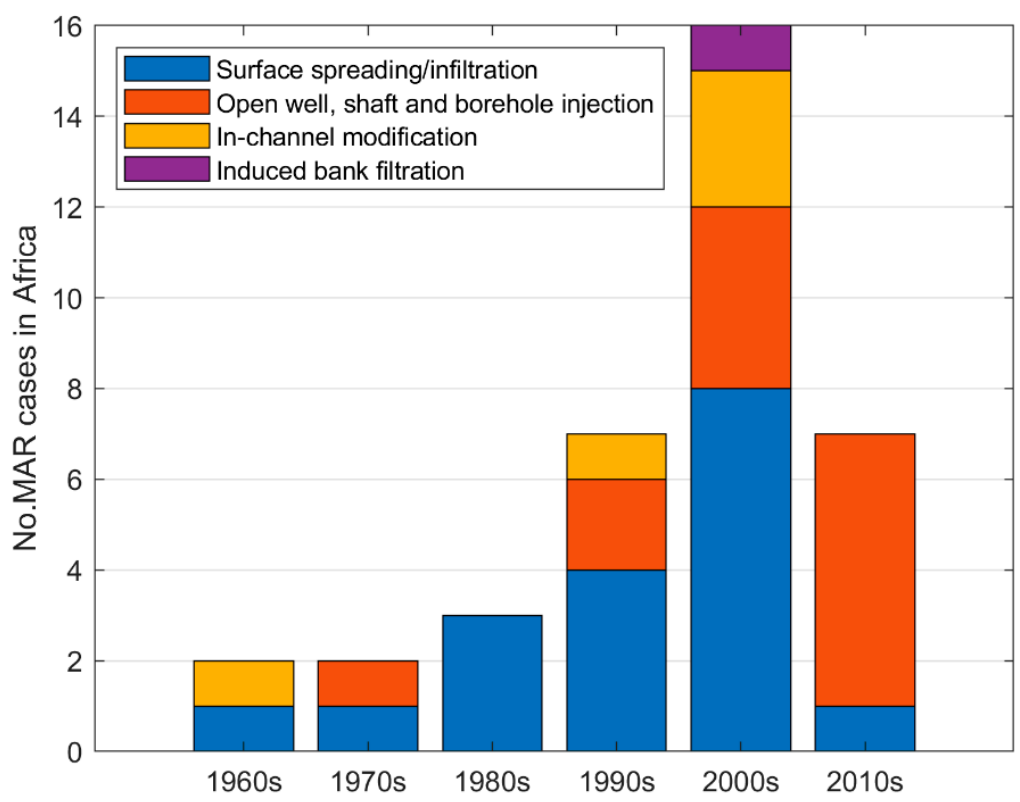

Figure 3. Historical development of MAR cases in Africa where starting date is known. For each decade, the number of new projects is given $(n=37)$.

The main source of water for the MAR schemes is river water. Thirty three out of the 52 cases use river water as a source and 11 cases use treated wastewater (Figure 4). Some schemes use several sources of water. The Atlantis scheme [18] uses both urban stormwater runoff and treated wastewater. The Windhoek scheme [15] uses river water and treated wastewater. Among the 33 cases that use river water, 19 cases use an ephemeral river as their water source, while eight cases rely on perennial rivers. Three of the eight cases that rely on perennial rivers are found in Egypt, using Nile River water. The Toushka and EI Bustan area, with two MAR schemes rely on Nile flood water for their source [37], while the Sidfa river bank filtration project relies on perennial flow of the Nile River [36]. Treated 
wastewater is used in countries with limited water resources, such as Atlantis, South Africa [18], Windhoek, Namibia [38], and Korba Cap Bon, Souil Wadi, Nabelul, Soukra, Nabeul-Hammamet, El Hajeb-Sidi Abid, Boumerdes and Mahdia-Ksour Essef, Tunisia [29]. The five MAR cases, which rely on groundwater as source of water are at: Williston, South Africa [39], Sishen Mine (Khai Appel), South Africa [25], Elandsfontein, South Africa [25], Kolomela South Africa [13,26], and Koraro-01, subsurface dam, Ethiopia [40]. The Williston case in South Africa [39], uses groundwater abstracted from one aquifer to recharge another aquifer compartmentalized by dykes while the other three cases in South Africa use dewatering water from mines.

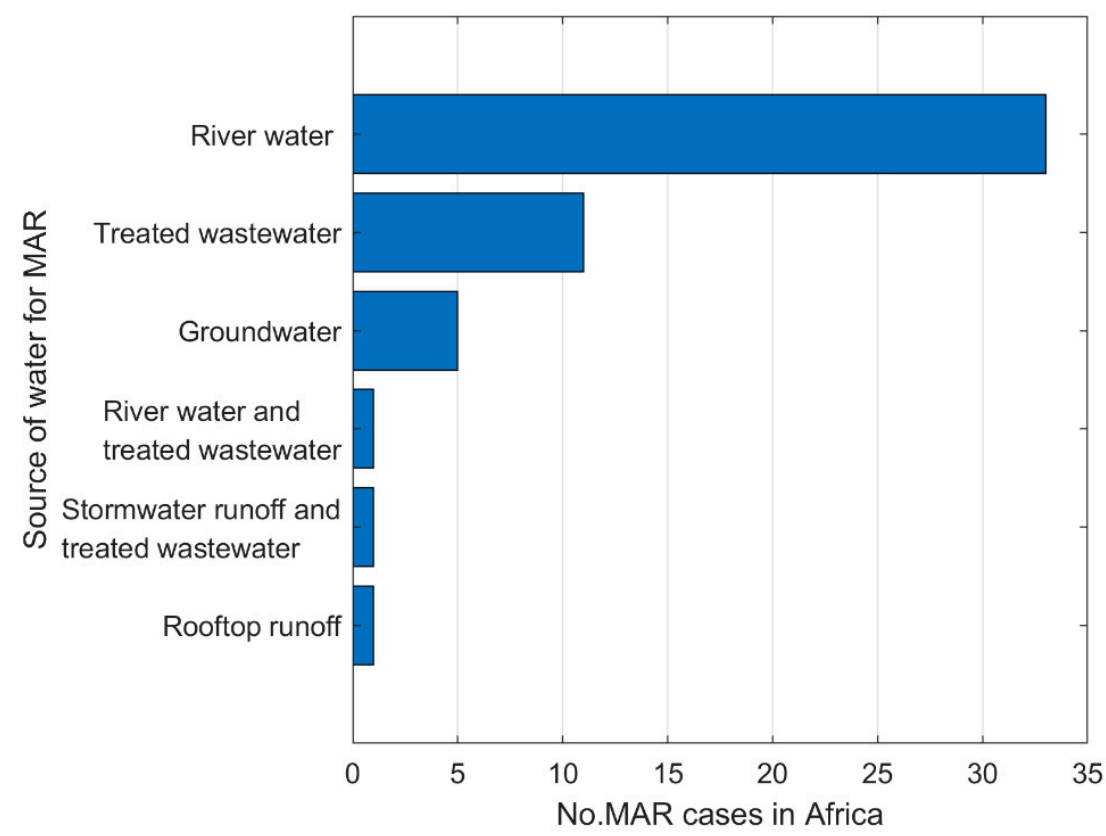

Figure 4. Number of MAR cases in Africa per water source $(n=52)$.

The key objective of the MAR schemes is to secure and augment water supply. Out of the 52 cases, 23 have a key objective focused exclusively on securing and augmenting water supply (Figure 5). Nine cases have key objectives focused on water quality improvement. Six cases have ameliorating groundwater level decline as key objective, while four cases have preventing seawater intrusion as key objective.

Examples of securing and augmenting water supply include purposes of increasing water availability to meet rural domestic demand during dry periods (e.g., sand dams in Kenya), of meeting summer peak demand (e.g., Prince Albert [41], and Plettenberg [42], South Africa). Examples of securing water supply in drought and emergency situations include Calvinia, South Africa [43] and Windhoek, Namibia [43]. Augmenting water supply and preventing seawater intrusion refers to storing water to meet domestic demand while simultaneously preventing seawater intrusion in the coastal aquifer. An example is the Atlantis scheme, South Africa [18], which separates the domestic and industrial wastewater and stormwater runoff based on salinity, recharges the low salinity water into the inland aquifer used for domestic supply, and recharges the more brackish water into the coastal aquifer to prevent seawater intrusion. Other examples of cases with a preventative seawater intrusion objective include El Khairat [44] and Teboulba [30] aquifers, Tunisia. Finally, the objective of improving water quality refers to water quality enhancement during infiltration (SAT) process (e.g., Ben Sergao, Morocco [45]). One case with an exclusive key objective of enhancing environmental flow is Elandsfontein, South Africa [25]. 


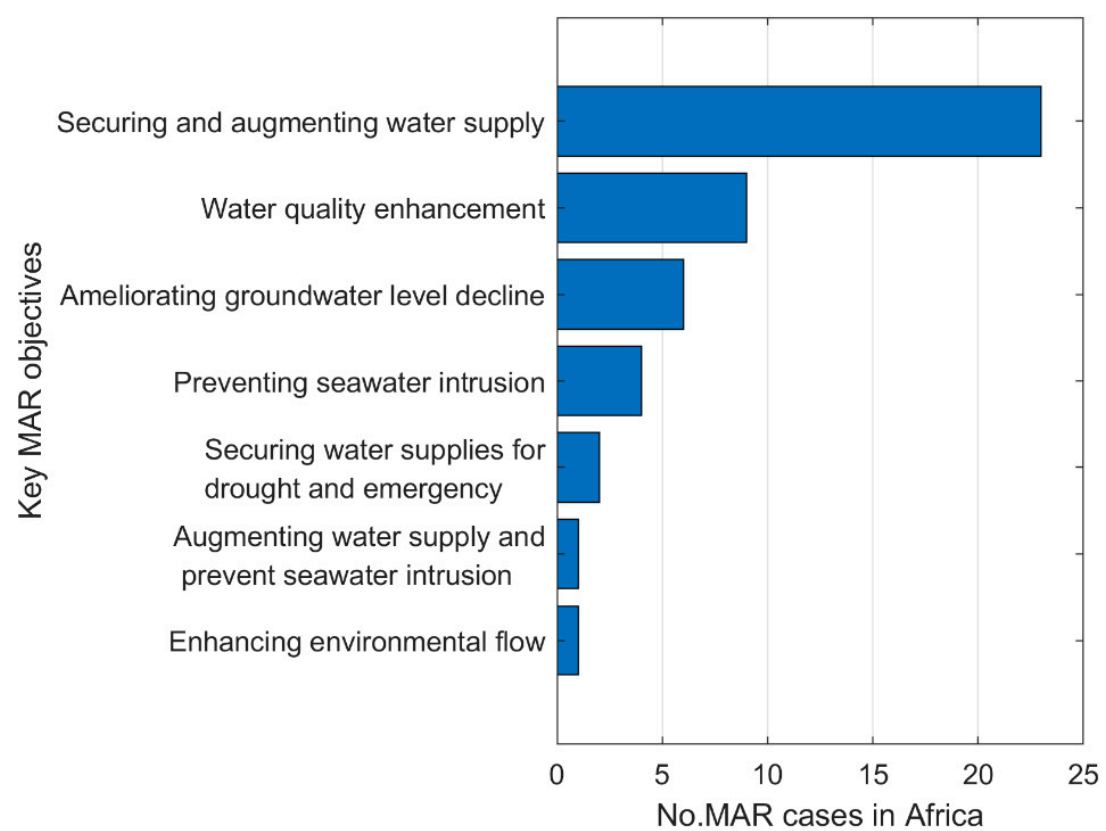

Figure 5. Number of MAR cases in Africa per MAR key objective where information is available $(n=46)$.

Rainfall across the MAR schemes varies widely. The average annual rainfall across the MAR sites ranges from 1-2225 mm/year (Figure 6a). The average annual rainfall across the MAR sites is $461 \mathrm{~mm} /$ year. The minimum and maximum average annual rainfall occurs in MAR sites in Toushka [37], Egypt and Michael Okpara University of Agriculture, Nigeria [46], respectively. The number of cases per five average annual rainfall interval classes is shown in Figure 7 . While just over $65 \%$ of cases are located in the low annual rainfall class ( $<500 \mathrm{~mm}$ /year), concentration of MAR cases in low rainfall geographies is not dominant.

MAR schemes are concentrated in regions of above-average levels of inter-annual variability in water availability. Eighty three percent of the MAR cases are located in regions of above average inter-annual variability in water availability (Figure 6b). Twenty one of the MAR cases are located in regions with 'medium to high' inter-annual variability, and another 17 cases in regions with 'high' variability (Figure 8). Five cases are located in 'extremely high' variability regions. Saaipoort [25,27,28], Sishen Mine (Khai Appel) [25], Smouskolk (Vanwyksvlei) [25], Williston [39], South Africa and Windhoek, Namibia [43] are the five cases in the extremely high inter-annual variability class. Conversely, only nine cases are located in collective regions of 'low' or 'medium to low' variability.

MAR cases are concentrated in highly populated regions. In total, 31 cases $(60 \%)$ are located in regions with population density greater than 100 inhabitants per square kilometer (ESM, Figure S1). Nonetheless, MAR experience is also found in less populated areas of e.g., Egypt, Namibia, South Africa and Tunisia. Cases with low population density could be explained by primary use for rural and irrigation use (Teboulba, Tunisia [30], El Hajeb-Sidi Abid, Tunisia [29]), or because water from MAR is subsequently transferred to population centers (Omaruru Delta (OMDEL), Namibia [47], Williston, South Africa [39]). 

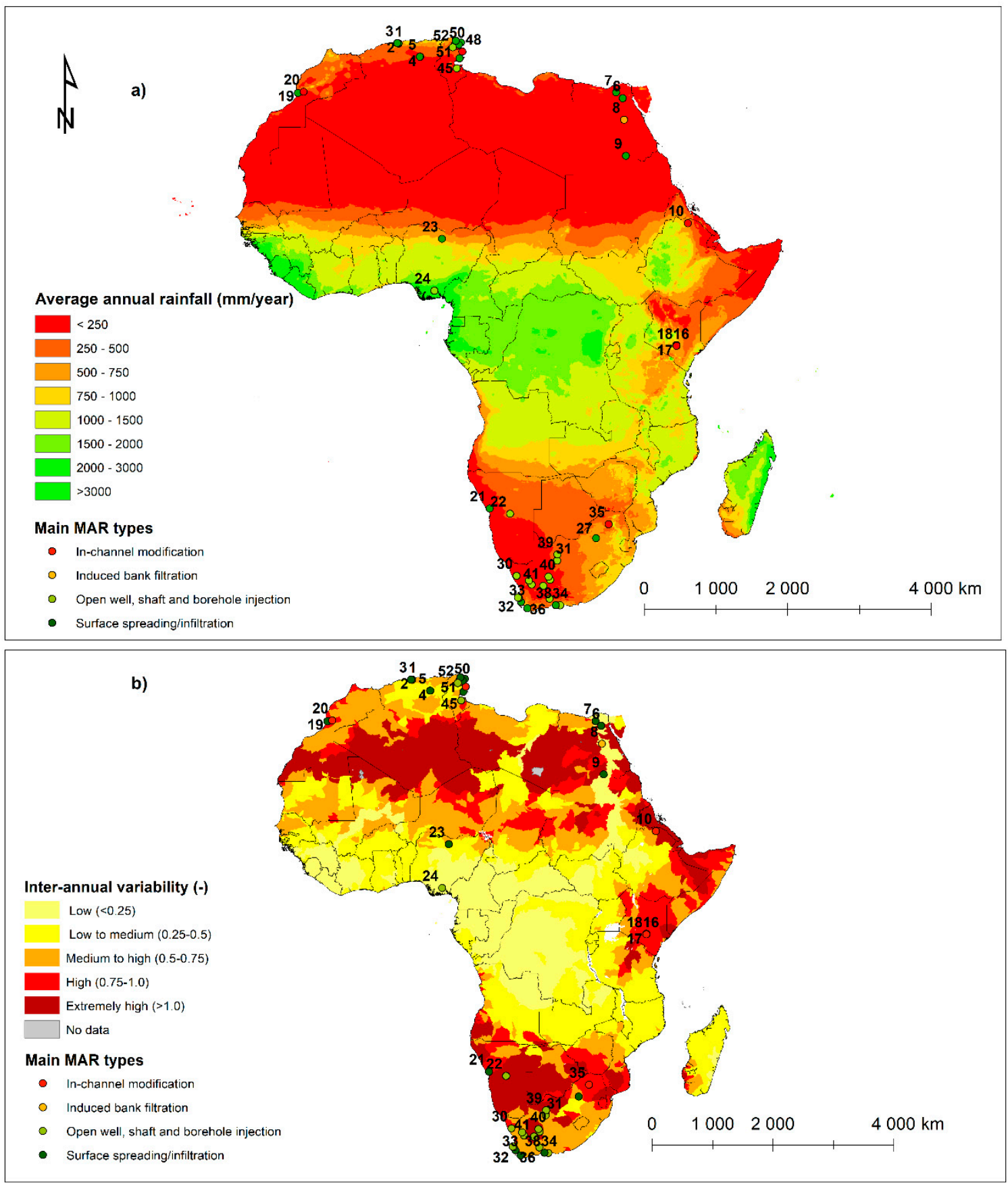

Figure 6. Location of MAR schemes in Africa overlaid on (a) average annual rainfall from Climate Hazards Group Infrared Precipitation with Stations (CHIRPS) [31] and (b) inter-annual variability in available surface water from Aqueduct Global Maps 2.1 [33]. MAR case labels corresponds to MAR cases numbering in Annex S1 and Annex S2 of the ESM. 


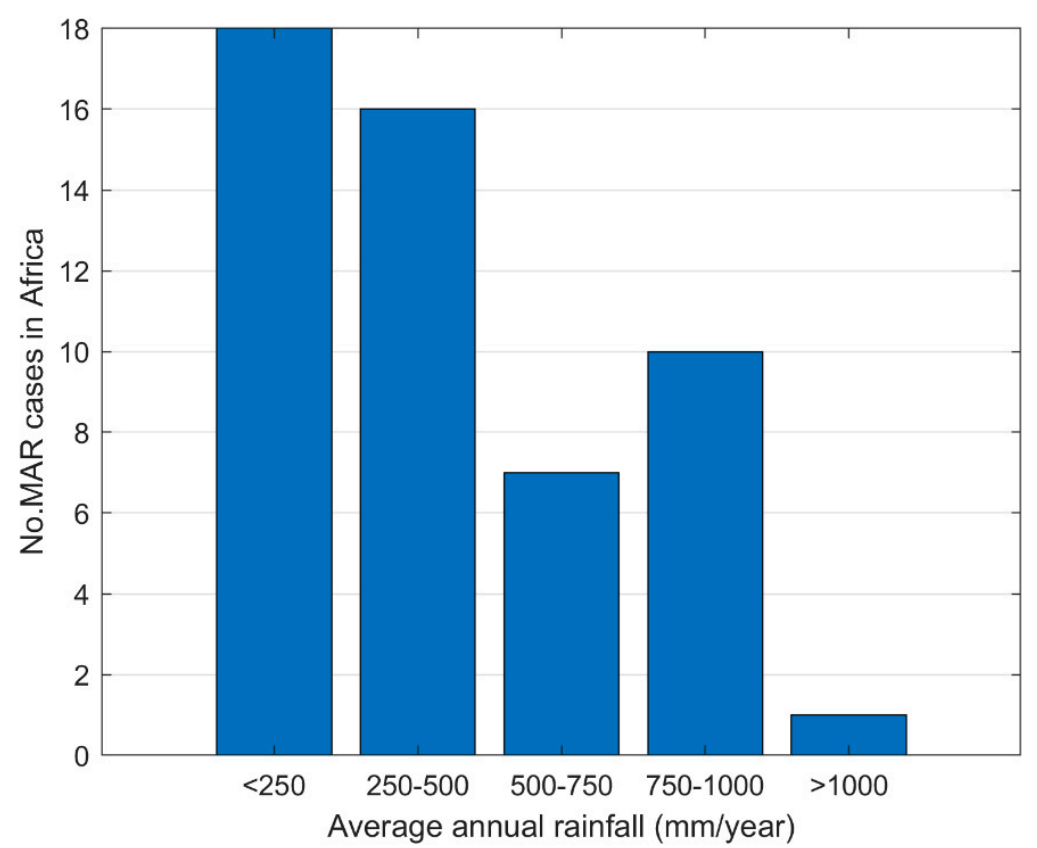

Figure 7. Number of MAR cases in Africa per average annual rainfall class $(n=52)$.

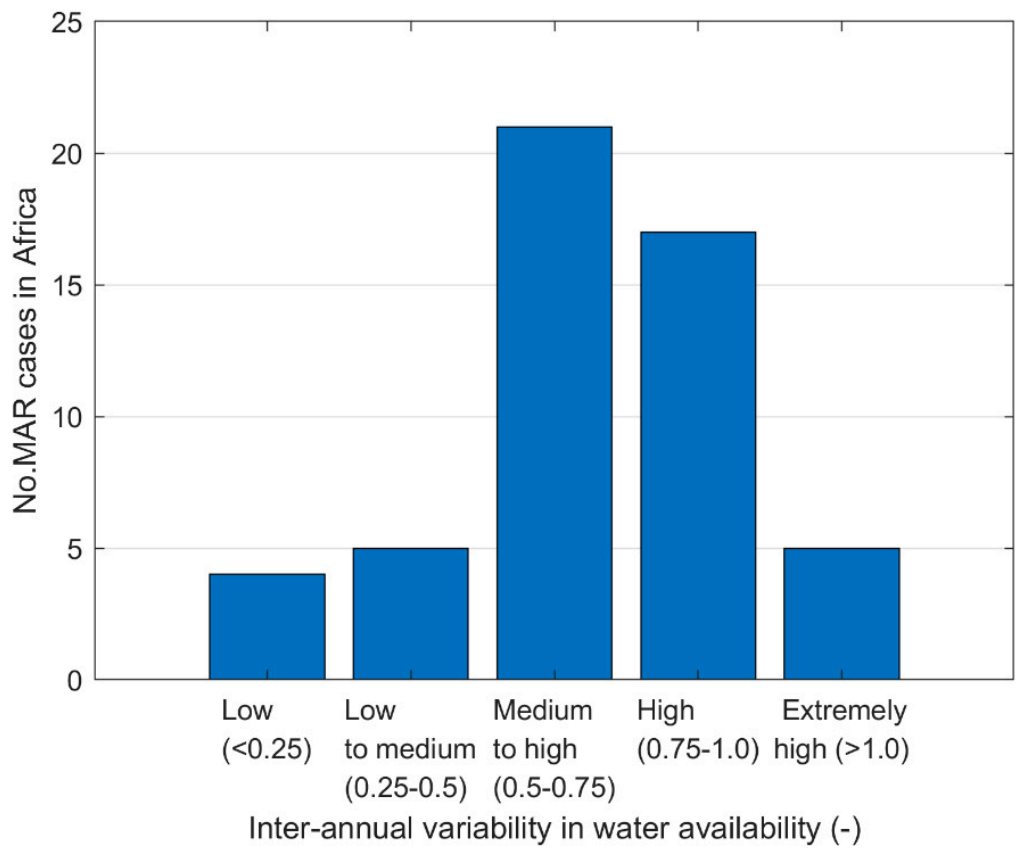

Figure 8. Number of MAR cases in Africa per inter-annual variability in surface water availability class $(n=52)$.

Few MAR schemes are located in transboundary aquifers. Six cases are found to be located in a transboundary aquifer. Four cases in Egypt are located in the Nubian Sandstone Aquifer system shared among Chad, Egypt, Libya and Sudan, one case in Ethiopia is located in the Mereb Aquifer shared between Ethiopia and Eritrea, and one case in Nigeria is located in the Lake Chad Aquifer shared among six countries: Algeria, Cameroon, Central Africa Republic, Chad, Niger and Nigeria. None of the MAR projects in these transboundary aquifers is believed to have significant transboundary concerns or impacts, as they are not located close to the national borders, and the magnitude of enhanced recharge is relatively small compared to the natural storage of the transboundary aquifers. 
The primary geological environment of the MAR cases is sedimentary aquifers. The majority of the MAR sites is situated in sedimentary aquifers $(n=42)$ and the rest $(n=10)$ is located in hard rock aquifers. This is expected, as sedimentary formations (e.g., carbonate, gravel, and sand) with various degree of consolidation or cementing are usually targeted for MAR [48]. MAR sites situated in sedimentary rocks are found in Egypt, Ethiopia, Morocco, South Africa and Tunisia. Igneous and metamorphic rocks are often loosely referred as hard rock due to their poor drill-ability [49] and have low primary porosity and most of their porosity comes from secondary porosity (cracks and fractures). Examples of MAR in hard rock are found in Kenya, Nigeria, Namibia and South Africa. The Windhoek case, Namibia [15] is a good example of a large-scale municipal use MAR scheme in fractured rock aquifer setting. Although, half of the sand dams $(n=4)$ in Kenya are located in hard (metamorphic) rock, the weathering product of the same (sand and gravel) produce eroded sediments, which constitute the actual aquifer used for MAR.

Sectoral use of the MAR schemes is predominantly domestic. The final use of the recovered MAR water across all schemes is presented in Figure 9. The dominant use of MAR is to support domestic water supply $(n=23)$, followed by agricultural use $(n=17)$, while only one scheme is solely used for industry (Eland Platinum Mine, South Africa [50]). Multiple purpose schemes have multiple uses of the MAR water (typically agricultural and domestic use, e.g., Loeriesfontein, South Africa [39,51], and domestic and environmental use, e.g., Atlantis, South Africa [18,52]). Despite classifying sand dams into domestic water supply, it is likely that the water is used for multiple purposes, including, livestock and garden agriculture [24]. The Elandsfontein, South Africa [25] is the only case with dominant use of MAR water for environmental flows.

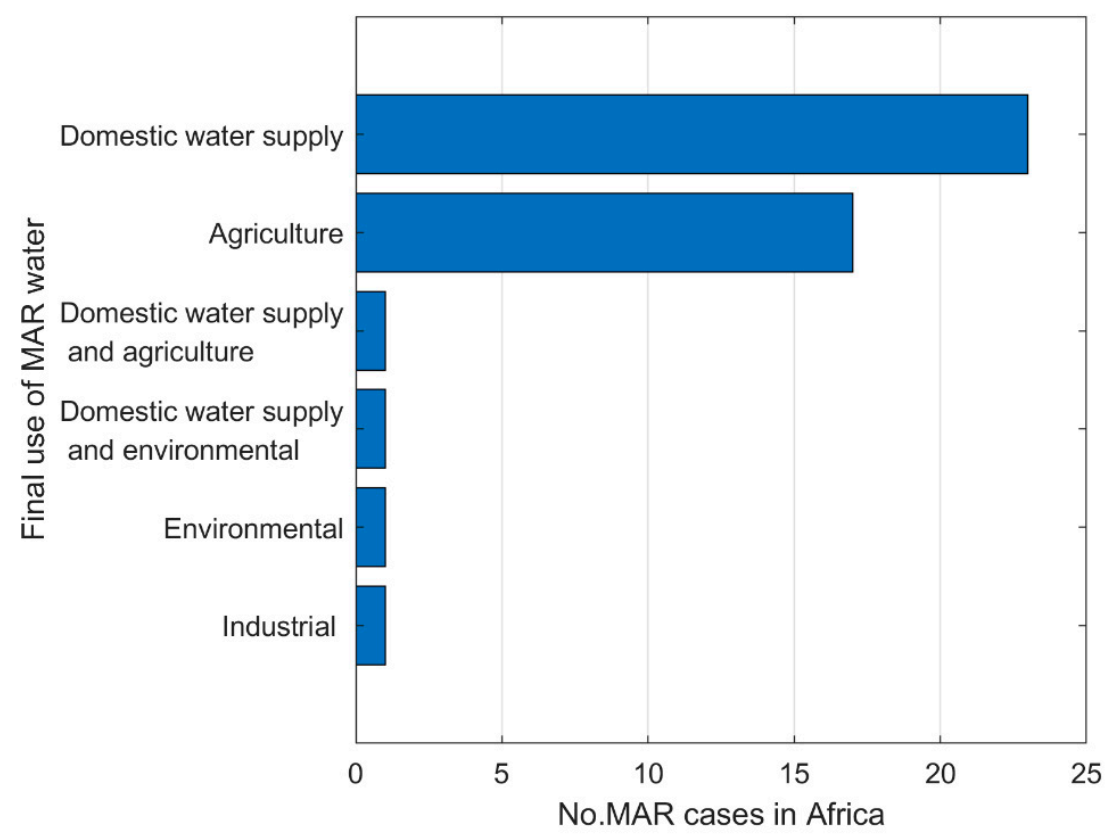

Figure 9. Number of MAR cases in Africa per final water use of stored water where information is available $(\mathrm{n}=44)$.

Recharge volume per MAR scheme varies widely. Recharge volume estimates (compiled as recharge volume per year) are available for 23 MAR cases in seven of the nine countries with recorded MAR schemes (Table 3). The recharge volume ranges from $0.001-100 \mathrm{Mm}^{3} /$ year, as estimated mostly from reported single daily recharge rates. The highest recharge volume was recorded for the Souss-Massa case, Morocco [53,54] and the lowest recharge volume was for the Koraro-01 subsurface dam (included in the in-channel modification MAR type), Ethiopia [40]. The high recharge volumes (Souss-Massa, Morocco [53,54]; Sidfa Riverbank Filtration, Egypt [36]; Omaruru Delta, Namibia [47]; and Atlantis, South Africa [18]) give an indication of the potential that MAR provides in terms of 
securing water supply (most notably in the dry season). Even the smallest recharge schemes, like Koraro-01, Ethiopia [40], provide a secured domestic water supply for rural communities.

Recharge volume per country is also quite variable (Table 4). The total annual recharge volume for Africa from full scale MAR is $158 \mathrm{Mm}^{3} /$ year. To compare, the value for Latin America and the Caribbean is $340 \mathrm{Mm}^{3} /$ year [20]. The Souss-Massa MAR scheme [53,54], which contributes the largest share of MAR recharge in Africa, makes use of Aoulouz and Imi El Kheng dams located in the upstream part of the Souss-Massa River basin to detain flood water and regulate release of water into the streambed downstream to match infiltration capacity of the streambed. The Souss-Massa River basin is one of the major River basins of Morocco located in the southwestern part of the country. The River basin is drained by two main rivers, the Souss River and the Massa River. The Souss River originates from the High Atlas Mountains in the northern part of the basin. The river is seasonal with occasional high floods between October and February. It is regulated by four big dams. The Massa River drains the Souss-Massa from the southern side of the River basin. Both rivers drain into the Atlantic Ocean. The Aoulouz and the Imi EI Kheng dams, two big dams located in the upstream part of the Souss River, are used for MAR mainly due to their favorable geologic conditions and good water quality [55]. The storage capacity of the Aoulouz and the Imi EI Kheng dams is 103 and $12 \mathrm{Mm}^{3}$, respectively. Based on monthly dam release data of 1991-2004, Bouchaou [53] estimate an annual recharge of $100 \mathrm{Mm}^{3}$ (86\% of total annual release), which is consistent with other studies [56]. The annual recharge volume is estimated using piezometeric water level fluctuations before and after dam release [54].

Table 3. Recharge volume per MAR case where information is available $(n=23)$.

\begin{tabular}{|c|c|c|c|c|}
\hline \multirow{2}{*}{ MAR Case } & \multirow{2}{*}{ Country } & \multicolumn{2}{|c|}{ Recharge Volume $\left(\mathrm{Mm}^{3} /\right.$ Year) } & \multirow{2}{*}{ Reference } \\
\hline & & Full Scale & Pilot Scale & \\
\hline Oued Biskra & Algeria & 1.7 & & [57] \\
\hline Sidfa Riverbank Filtration & Egypt & 22.0 & & {$[36]$} \\
\hline Koraro-01 & Ethiopia & 0.001 & & [40] \\
\hline Souss-Massa & Morocco & 100 & & [53] \\
\hline Omaruru Delta & Namibia & 9.0 & & [47] \\
\hline Windhoek & Namibia & 2.8 & & [13] \\
\hline Atlantis ${ }^{1}$ & South Africa & 4.2 & & {$[13,18]$} \\
\hline Calvinia & South Africa & & 0.8 & {$[43]$} \\
\hline Elandsfontein ${ }^{2}$ & South Africa & 5.6 & & [25] \\
\hline Hermanus & South Africa & & 1.5 & [58] \\
\hline Kharkams & South Africa & 0.005 & & [47] \\
\hline Kolomela & South Africa & 0.7 & & [13] \\
\hline Plettenberg Bay & South Africa & & 0.3 & [42] \\
\hline Polokwane & South Africa & 4.5 & & [43] \\
\hline Sedgefield & South Africa & & 0.5 & [58] \\
\hline Smouskolk (Vanwyksvlei) & South Africa & 1.1 & & [25] \\
\hline Williston & South Africa & 0.1 & & [39] \\
\hline El Hajeb-Sidi Abid & Tunisia & 0.1 & & [29] \\
\hline El Khairat & Tunisia & 3.3 & & [29] \\
\hline Jeffara Plain (Oum Zessar) & Tunisia & 1.2 & & [57] \\
\hline Khalidia & Tunisia & 0.8 & & [59] \\
\hline Korba, Cap Bon & Tunisia & 0.5 & & [29] \\
\hline Teboulba & Tunisia & 0.2 & & [30] \\
\hline Total & & 157.8 & 3.1 & \\
\hline
\end{tabular}

${ }^{1}$ Recharge volume for the Atlantis scheme, South Africa is around $2.7 \mathrm{Mm}^{3} /$ year, but an additional $1.5 \mathrm{Mm}^{3} /$ year more brackish salinity water is recharged in coastal aquifers for seawater control. ${ }^{2}$ Annual recharge volume is obtained from Fanus Fourie, DWS (Department of Water and Sanitation), and South Africa (personal communication). 
Table 4. Recharge volume per country and recharge as percentage of groundwater use, arranged by recharge volume, where information is available $(n=23)$.

\begin{tabular}{|c|c|c|c|c|}
\hline \multirow{2}{*}{ Country } & \multicolumn{2}{|c|}{ Recharge Volume $\left(\mathrm{Mm}^{3} /\right.$ Year $)$} & \multirow[t]{2}{*}{$\begin{array}{l}\text { Groundwater Use } \\
\left(\mathrm{Mm}^{3} / \text { Year }\right)^{3}\end{array}$} & \multirow{2}{*}{$\begin{array}{l}\text { Recharge Volume as } \\
\text { Percentage of } \\
\text { Groundwater Use (\%) }\end{array}$} \\
\hline & Full Scale & Pilot Scale & & \\
\hline Morocco & 100 & & 3060 & 3.3 \\
\hline Egypt & 22.0 & & 7780 & 0.3 \\
\hline South Africa & 16.2 & 3.1 & 3140 & 0.5 \\
\hline Namibia & 11.8 & & 150 & 7.9 \\
\hline Tunisia & 6.1 & & 2020 & 0.3 \\
\hline Algeria & 1.7 & & 2870 & 0.1 \\
\hline Ethiopia & 0.001 & & 1490 & 0.0 \\
\hline Kenya & - & & 620 & \\
\hline Nigeria & - & & 3440 & \\
\hline Total & 157.8 & & 24,570 & 0.6 \\
\hline
\end{tabular}

${ }^{3}$ Groundwater use for 2010 from Margat and van der Gun [7].

Recharge volume as percentage of groundwater use per country is also variable. Recharge volume as percentage of groundwater use per country is calculated using recharge volume for operational MAR schemes and groundwater use data from 2010, as reported by Margat and van der Gun [7] (Table 4). Recharge volume as percentage of groundwater use is highest in Namibia (7.9\%) followed by Morocco (3.3\%) and South Africa (0.5\%).

Recharge volume as percentage of groundwater use is the least for Africa compared to other continents. The total groundwater use in 2010 for countries in Africa reported by Margat and van der Gun [7] is $41,640 \mathrm{Mm}^{3} /$ year. Based on this, MAR as percentage of groundwater use in Africa is $0.4 \%$, which is close to the estimate for South America (0.5\%) but low compared to other continents, e.g., Middle East (9.4\%), Oceania (8.3\%), Europe (6.3\%), North America (2.3\%) and Asia (1.8\%) [13] (See also Table S4 of the ESM).

Summary of MAR cases per country. In Morocco, both surface spreading/infiltration and in-channel modification are practiced in equal share. The main objective of MAR is water quality improvement as well as ameliorating groundwater level decline. River water (Souss-Massa [53,54]) and treated wastewater (Ben Sergao [45]) are used as a main water sources for MAR in Morocco, and the final use of recovered MAR water is for agriculture. In Egypt, the main MAR type is surface spreading/infiltration, the main objective of MAR is to secure and augment water supply, the main water source is river water, and the final use of MAR water is domestic water supply. In South Africa, the main MAR type is open well, shaft and borehole injection, the main objective of MAR is to secure and augment water supply, the main water source for MAR is river water, and the final use of recovered MAR water is domestic water supply. In Namibia, both surface spreading/infiltration (Omaruru Delta [47]) and borehole injection (Windhoek $[38,43]$ ) are practiced. The main objective of MAR is to secure water supplies in drought and emergency situations as well as ameliorating groundwater level decline. River water and treated wastewater are used as a main water sources for MAR, and the final use of recovered MAR water is for domestic water supply.

In Tunisia, the main MAR type is surface spreading/infiltration method, the main objective of MAR is water quality improvement, the main source of water for MAR is treated wastewater, and the final use of MAR water is for agriculture. In Algeria, the main MAR type is surface spreading/infiltration methods, the main source of water is river water and the final use of recovered MAR water is for agriculture. In Ethiopia, the only analyzed case is a subsurface dam constructed near the village of Koraro [40]. The Koraro-01 subsurface dam supplies domestic water. In Kenya, the main MAR type is in-channel modification (sand dams), the main objective of MAR is to secure and augment water supply, the main water source is river water, and the final use of MAR water is domestic water supply. 
In Nigeria, surface spreading/infiltration and open well, shaft and borehole injection are practiced equally prevalently. The main objective of MAR is to ameliorate declining groundwater levels, and the main source of water is river water.

\section{Discussion and Conclusions}

This article has compiled information on 52 well-reported MAR cases in Africa in order to develop a baseline in understanding of the breadth and status of MAR in Africa. A classification framework was developed and applied to the set of MAR cases, in order to make a first-order assessment based on existing data. Despite the relatively small sample $(n=52)$, the analysis has generated six significant findings.

First, MAR implementation is not extensive in Africa and is concentrated in nine of the continent's 54 countries. The extent of MAR implementation in Africa remains low compared to other continents [21]. However, the volume reported here $\left(158 \mathrm{Mm}^{3} /\right.$ year $)$ significantly exceeds the only documented summary of MAR in Africa, which was for Southern Africa, presented by Dillon et al. [13] (10 $\mathrm{Mm}^{3} /$ year for 2015). MAR as fraction of groundwater use in the Southern African region is now estimated at $0.6 \%$, which is three times the reported value by Dillon, et al. [13]. This increase is partially explained by new cases coming into operation since 2015 (e.g., Elandsfontein [25]) or additional cases included in this study (e.g., Omaruru Delta [47].

The number of MAR cases in Asia, Europe, North America, Oceania and South America from the Global MAR Portal is281, 282, 308, 95and 113, respectively [22]. Still, there are cases in Southern and Northern Africa that have more than 30 years of MAR practice (e.g., Atlantis, South Africa [18], Teboulba, Tunisia [30]). Overall, the extent of MAR practice in Africa is low considering the high variability in surface water availability. Major factors that limit wider application of MAR in Africa may include lack of: (1) awareness of and experience with MAR, (2) financial resources, (3) human and institutional capacity, (4) enabling policy frameworks, (5) sufficient and sufficiently well-functioning demonstration sites, (6) understanding of aquifer hydrogeology and geochemical properties.

Second, the key objective of the MAR schemes is to secure and augment water supply and balance inter-seasonal variability in supply and demand. This is consistent with the study in Latin America and the Caribbean by Valverde et al. [20]. For example, the Atlantis scheme, South Africa [18] contributes approximately 25-30\% of the water supply of Atlantis Town and has recently been proposed for an expansion to support future drought resilience of Cape Town [60]. The Calvinia case, South Africa [43] is reported to have the potential to provide two to three months of the water supply to Calvinia Town. According to Murray [14], when developed in the next phase, the Windhoek case, Namibia [38,43] is expected to provide a drought buffer as the main water resource for the city for up to three years. As such, Africa presents an initial set of cases and experiences, on which to further develop and upscale the benefits of MAR in the continent.

Third, the main MAR type is the surface spreading/infiltration method. This is different from other continents, e.g., in Europe (induced bank filtration is dominant) [19], and Latin America and the Caribbean (in-channel modification) [20]. In Africa, while sand dams are practiced widely in Kenya, open well, shaft and borehole injection methods are relatively more common in Southern Africa.

Fourth, and linking to point two, a central bio-physical factor that appears to explain MAR location is variability in water availability. The majority (83\%) of the MAR sites in Africa are located in geographic regions with above average inter-annual variability in water availability. This is expected as one of the main purposes of MAR is to buffer short-term, seasonal and across-year-variability in water supply. Population density, representing water demand (Figure S1, ESM) and technical and financial capacity are additional factors that may help explain MAR uptake in Africa. Surface spreading/infiltration methods and open well, shaft and borehole injection methods are mostly used for larger urban supply systems, whereas sand dams and subsurface dams for smaller rural systems. As such, there is an apparent dichotomy between MAR systems in Africa governed by demand setting, investment environment, water sources to be applied for MAR (with increasing use of treated 
wastewater in urban settings) and the management schemes required to address the various issues of financial feasibility and technical maintenance. It is important to note that wastewater reuse should only be encouraged if groundwater quality protection measures are demonstrated effective, which requires guidelines, monitoring and analysis capability. Water from MAR in rural areas also tend to have more variety in use requirements compared with municipal systems, which cater mostly to domestic and industrial uses.

Fifth, while not exhaustive, our study pinpointed some general challenges with MAR in Africa (ESM, Table S4). In total, 13 cases (28\%) were reported to have a challenge related to site selection and design or to operation and maintenance. Shallow unsaturated zone thickness was identified as a problem in two surface spreading/infiltration MAR cases (Atlantis case, South Africa [18]) and Polokwane, South Africa [43]. The unsaturated zone of one of the basins of the Atlantis case is reported to be fully saturated during the rainy season, which affects the storage and water quality improvement capacity of the system [18]. In the Polokwane case, South Africa [43], due to insufficient unsaturated zone thickness, there is a concern that some bacteria, viruses or parasites could survive and contaminate groundwater.

Site selection problems were identified as main reasons for underperformance or failure of some sand dams in Kenya [24,61,62]. Site selection may affect rate of sand deposition behind the dam, hence, the time to reach full storage capacity. As an example, three sand dams located in the upstream part of a catchment were reported to have very low infiltration capacity and storage due to the existence of a silt layer in the accumulated sediment, and it took nine years for the sand dam to reach its full storage capacity [24]. Similarly, siting sand dams in areas with a high depth to impermeable bedrock was found to be a problem giving rise to excessive leakage of stored water underneath the dam and scouring of dam foundation [24]. Site selection was a problem in the Abu Rawash case, Egypt [63], where the infiltration basin was sited in clay soil with low infiltration rate.

Infrastructure design problems were reported in the Kharkams well injection case, South Africa [43] and in the in-channel modification Koraro-01 case, Ethiopia [40]. Filter design was an issue in the Kharkams injection MAR scheme, where sand was entering the injection borehole, resulting in a clogging problem [43], whereas the problem at Koraro-01 was the infrastructural design that resulted in breaching of above ground situated subsurface dam crest due to flooding [40]. For some infiltration schemes, i.e., Atlantis, South Africa [18], the Omaruru Delta, Namibia [47] and Abu Rawash, Egypt [63], clogging of infiltration basins or recovery wells, created problems. For example, in Atlantis, South Africa, elevated iron and sulfate in the groundwater caused biological iron-related clogging in recovery wells [18].

Mixing of recharge water with poor inherent water quality in the aquifer was identified as a concern at two MAR sites, Calvinia [43] and Eland Platinum Mine [50,64], both in South Africa. The Calvinia site uses underground natural breccia pipes as storage of MAR water due to their excellent hydraulic confinement and because of the poor surrounding water quality. According to Murray and Tredoux [43], the breccia pipes used in Calvinia are about $100 \mathrm{~m}$ in diameter and are very poorly connected to the Karoo sequence aquifer in which they are located. Since the surrounding aquifer already contains high $\mathrm{pH}$, fluoride and arsenic that exceed drinking water standards, there is a concern that the quality of abstracted water could be compromised due to mixing of recharged water with inherently contaminated aquifer water [43]. Use of abandoned mining and quarry sites may reduce costs associated with infrastructure of MAR storage. However, risk of mixing with poor quality water from mining activities may be a concern. For the Eland Platinum Mine, South Africa [50,64], high nitrate and electrical conductivity levels were a concern. Risk of heavy metal contamination from the mining activity is also possible, but data are not available to determine the level of risk. Some of the measures for addressing the above challenges are presented in Table S5 of the ESM. Existing guidelines developed in Australia and elsewhere provide useful guidance for planning and implementation, monitoring and evaluation of MAR (e.g., [39,65-67]). By following approaches presented in these guidelines, problems can be anticipated and counteracted. Re-siting or re-designing projects, and pro-actively 
investigating how the schemes can best be monitored and managed are key to effective operation and sustainable outcomes.

Before concluding this discussion it is worth noting that there are other types of aquifer recharge enhancement in Africa that extend beyond those examined in this article. These include cases of road water harvesting [68,69]; spate irrigation [70], and rainwater harvesting [71-73]. Road water harvesting is a type of water harvesting technique where concentrated runoff generated by or along roads is collected using adjacent ponds or channeled to farm land [69,74], which assists road drainage as well as crops, and may incidentally enhance recharge. Spate irrigation is an irrigation technique, by which seasonal river water is diverted and spread to a larger riparian surface areas, primarily to enhance soil moisture for growing crops, and this would also incidentally enhance recharge.

\section{Looking Forward}

This paper is the first to systematically examine reported MAR schemes over the African continent and review experiences. While only 52 cases are reported, they provide about $158 \mathrm{Mm}^{3} /$ year of additional water storage to enhance water supply and/or water quality. This volume represents $0.4 \%$ of continental groundwater use, but plays a critical role in locally supplying and securing water for large populations. Examples of technical challenges were revealed that could be a deterrent to future African investment in MAR, unless these are systematically addressed. Observations from MAR practices around the world suggest that guidelines and policies can help to prevent or overcome such problems. South Africa has advanced significantly in this regard with a national map showing the prospects for MAR [51], a manual on how to develop MAR projects [75], and well-documented case studies [58]. Wider adoption of this approach would well serve other African nations.

Furthermore, impact assessment, including pre-project baseline assessment and continuous monitoring are warranted for significant MAR schemes to reveal their performance and long-term outcomes with respect to water security and resilience. Maintenance and financial, institutional and socio-economic aspects are also key elements to sustainability, which needs increased attention. Hence, strong feasibility analysis, performance and impact assessment of existing and new MAR projects should be a primary focus going forward.

Supplementary Materials: The following are available online at http://www.mdpi.com/2073-4441/12/7/1844/s1. References [76-86] are cited in the supplementary materials. An Electronic Supplementary Material (ESM) summarizing MAR cases information. Figure S1: Location of 52 MAR cases in Africa overlaid on population density map of 2015, Table S1: MAR cases per key objectives per country (arranged by total number of MAR cases), Table S2: MAR case studies per source of recharge water per country, Table S3: MAR cases per final use of recovered water per country, Table S4: Recharge volume, absolute and as percentage of groundwater use in different continents or regions, ordered by MAR in 2015, Table S5: Challenges and possible solutions in MAR implementation, Annex S1: MAR cases in Africa (MAR scheme information), Annex S2: MAR cases in Africa (MAR site information).

Author Contributions: G.Y.E. led the development of this work including analysis of cases and write-up and prepared the original draft. J.F.L. contributed in conceptual direction and to draft preparation and in the review. K.G.V. contributed to the conceptual framework and review. All authors have read and agreed to the published version of the manuscript.

Funding: This study was undertaken in the context of and funded by the Potential Role of the Transboundary Ramotswa Aquifer-2 project, funded by the United States Agency for International Development (USAID) under the terms of Award No. AID-674-IO-17-00003, the CGIAR Research Program on Water, Land and Ecosystems (WLE) supporting the Groundwater Solutions Initiatives for Policy and Practices (GRIPP), and the Conjunctive Management across Borders in SADC project, also funded by USAID.

Acknowledgments: The authors would like to thank Fanus Fourie (Department of Water and Sanitation, South Africa), Habib Chaieb, (Directeur chez DHER-CRDA de Ben Arous-MARHP El Mourouj, Ben Arous Governorate, Tunisia), and Lhoussaine Bouchaou (Department of Earth Sciences, University Ibn Zohr Agadir, Morocco), and the International Groundwater Resources Assessment Center (IGRAC) for providing support in terms of case study information, and the two anonymous reviewers and the editor for providing constructive comments, which greatly improved the manuscript.

Conflicts of Interest: The authors declare no conflict of interest. 


\section{References}

1. IPCC. Climate Change 2007-The Physical Science Basis: Working Group I Contribution to the Fourth Assessment Report of the IPCC; Solomon, S., Qin, D., Manning, M., Averyt, K., Marquis, M., Eds.; Cambridge University Press: Cambridge, UK; New York, NY, USA, 2007; Volume 4.

2. Sadoff, C.W.; Hall, J.W.; Grey, D.; Aerts, J.C.J.H.; Ait-Kadi, M.; Brown, C.; Cox, A.; Dadson, S.; Garrick, D.; Kelman, J.; et al. Securing Water, Sustaining Growth: Report of the GWP/OECD Task Force on Water Security and Sustainable Growth; University of Oxford: Oxford, UK, 2015; p. 180.

3. African Ministers Council on Water. Water Security and Climate Resilient Development, Strategic Framework; African Ministers Council on Water: Abuja, Nigeria, 2012.

4. Cobbing, J.; Hiller, B. Waking a sleeping giant: Realizing the potential of groundwater in Sub-Saharan Africa. World Dev. 2019, 122, 597-613. [CrossRef]

5. Lautze, J.; Holmatov, B.; Saruchera, D.; Villholth, K.G. Conjunctive management of surface and groundwater in transboundary watercourses: A first assessment. Water Policy 2018, 20, 1-20. [CrossRef]

6. Megdal, S.B.; Dillon, P. Policy and Economics of Managed Aquifer Recharge and Water Banking. Water 2015, 7, 592-598. [CrossRef]

7. Margat, J.; van der Gun, J. Groundwater around the World: A Geographic Synopsis; CRC Press: Boca Raton, FL, USA, 2013.

8. Tuinhof, A.; Foster, S.; van Steenbergen, F.; Talbi, A.; Wishart, M. Appropriate Groundwater Management Policy for Sub-Saharan Africa: In Face of Demographic Pressure and Climatic Variability; World Bank: Washington, DC, USA, 2011.

9. Bouwer, H. Integrated water management: Emerging issues and challenges. Agric. Water Manag. 2000, 45, 217-228. [CrossRef]

10. Bouwer, H. Artificial recharge of groundwater: Hydrogeology and engineering. Hydrogeol. J. 2002, 10, 121-142. [CrossRef]

11. Asano, T.; Cotruvo, J.A. Groundwater recharge with reclaimed municipal wastewater: Health and regulatory considerations. Water Res. 2004, 38, 1941-1951. [CrossRef]

12. Ebrahim, G.Y.; Fathi, S.; Lautze, J.; Ansems, N.; Villholth, K.G.; Nijste, G.-J.; Magombeyi, M.; Mndaweni, S.; Kenabatho, P.; Moehadu, M.; et al. Review of Managed Aquifer Recharge (MAR) Experience in Africa and MAR Suitability Mapping for Ramotswa Transboundary Aquifer Area; International Water Management Institute: Pretoria, South Africa, 2017.

13. Dillon, P.; Stuyfzand, P.; Grischek, T.; Lluria, M.; Pyne, R.D.G.; Jain, R.C.; Bear, J.; Schwarz, J.; Wang, W.; Fernandez, E.; et al. Sixty years of global progress in managed aquifer recharge. An overview of Managed Aquifer Recharge in Southern Africa. Hydrogeol. J. 2019, 27, 1-30. [CrossRef]

14. Murray, R. Managed Aquifer Recharge, an Introductory Guide for the SADC Groundwater Management Institute Including the Windhoek Case Study; Groundwater Africa: Cape Town, South Africa, 2017.

15. Murray, R.; Louw, D.; van der Merwe, B.; Peters, I. Windhoek, Namibia: From conceptualising to operating and expanding a MAR scheme in a fractured quartzite aquifer for the city's water security. Sustain. Water Resour. Manag. 2018, 4, 217-223. [CrossRef]

16. Bugan, R.D.; Jovanovic, N.; Israel, S.; Tredoux, G.; Genthe, B.; Steyn, M.; Allpass, D.; Bishop, R.; Marinus, V. Four decades of water recycling in Atlantis (Western Cape, South Africa): Past, present and future. Water SA 2016, 42, 577-594. [CrossRef]

17. Jovanovic, N.; Bugan, R.D.; Tredoux, G.; Israel, S.; Bishop, R.; Marinus, V. Hydrogeological modelling of the Atlantis aquifer for management support to the Atlantis Water Supply Scheme. Water SA 2017, 43, 122-138. [CrossRef]

18. DWA. The Atlantis Water Resource Management Scheme: 30 Years of Artificial Groundwater Recharge; PRSA 000/001/1169/10-Activity 17 (AR5.1); Department of Water Affairs: Pretoria, South Africa, 2010.

19. Sprenger, C.; Hartog, N.; Hernández, M.; Vilanova, E.; Grützmacher, G.; Scheibler, F.; Hannappel, S. Inventory of managed aquifer recharge sites in Europe: Historical development, current situation and perspectives. Hydrogeol. J. 2017, 25, 1909-1922. [CrossRef]

20. Valverde, J.P.B.; Stefan, C.; Nava, A.P.; da Silva, E.B.; Vivar, H.L.P. Inventory of managed aquifer recharge schemes in Latin America and the Caribbean. Sustain. Water Resour. Manag. 2018, 4, 163-178. [CrossRef] 
21. Stefan, C.; Ansems, N. Web-based global inventory of managed aquifer recharge applications. Sustain. Water Resour. Manag. 2018, 4, 153-162. [CrossRef]

22. IGRAC. International Groundwater Resources Assessment Centre (IGRAC) Global MAR Portal. Available online: https://www.un-igrac.org/ggis/mar-portal (accessed on 6 May 2020).

23. Wipplinger, O. The Storage of Water in Sand; an Investigation of the Properties of Natural and Artificial Sand Reservoirs and of Methods of Developing such Reservoirs; South West Africa Administration Water Affairs Branch: Windhoek, Namibia, 1958.

24. Gijsbertsen, C.; Groen, J. A Study to Up-Scaling of the Principle and Sediment (Transport) Processes behind, Sand Storage Dams, Kitui District, Kenya. Master's Thesis, Vrije Universiteit, Amsterdam, The Netherlands, 2007.

25. Fourie, F.; Vermaak, N.; Hohne, D.; Murray, R. Authorising MAR projects within the context of South Africa's National Water Act. In Proceedings of the 9th International Symposium on Managed Aquifer Recharge (ISMAR9), Mexico City, Mexico, 20-24 June 2016.

26. Murray, R.; Baker, K. Kolomela Mine: Results of the Injection Tests in Groenwaterspruit for Mine Water Disposal, Groundwater Africa, South Africa; Groundwater Africa: Cape Town, South Africa, 2012.

27. Esterhuyse, C.J. Carnarvon: Report on Artificial Recharge Investigation at Saaipoort, Northern Cape Province Report Prepared by SRK Consulting (South Africa) (Pty) Ltd. for Aurecon South Africa (Pty) Ltd.; SRK Consulting: Cape Town, South Africa, 2019.

28. Hohne, D. Drought in the Northern Cape Karoo: Lessons learned and options for future use. In Proceedings of the 15th Biennial Ground Water Division Conference, Stellenbosch, South Africa, 14-18 October 2017.

29. Chaieb, H. Tunisian Experience in Artificial Recharge using Treated Waste Water. In Proceedings of the Regional Conference on Sustainable Integrated Wastewater Treatment and Reuse, Sharm El Sheikh, Egypt, 1-2 December 2014.

30. Bouri, S.; Dhia, H.B. A thirty-year artificial recharge experiment in a coastal aquifer in an arid zone: The Teboulba aquifer system (Tunisian Sahel). C. R. Geosci. 2010, 342, 60-74. [CrossRef]

31. Funk, C.C.; Peterson, P.J.; Landsfeld, M.F.; Pedreros, D.H.; Verdin, J.P.; Rowland, J.D.; Romero, B.E.; Husak, G.J.; Michaelsen, J.C.; Verdin, A.P. A quasi-global precipitation time series for drought monitoring. US Geol. Surv. Data Ser. 2014, 832,1-12.

32. World Resources Institute. Aqueduct Global Maps 2.1 Data. Available online: https://www.wri.org/resources/ data-sets/aqueduct-global-maps-21-data (accessed on 7 June 2018).

33. Gassert, F.; Luck, M.; Landis, M.; Reig, P.; Shiao, T. Aqueduct Global Maps 2.1: Constructing Decision-Relevant Global Water Risk Indicators; World Resources Institution: Washington, DC, USA, 2014.

34. IGRAC; UNESCO-IHP. Transboundary Aquifers of the World. 2015. Available online: http://ihp-wins.unesco. org/layers/geonode:tba_map2015 (accessed on 5 September 2018).

35. Hartmann, J.; Moosdorf, N. The new global lithological map database GLiM: A representation of rock properties at the Earth surface. Geochem. Geophys. Geosyst. 2012, 13. [CrossRef]

36. Shamrukh, M.; Abdel-Wahab, A. Riverbank filtration for sustainable water supply: Application to a large-scale facility on the Nile River. Clean Technol. Environ. Policy 2008, 10, 351-358. [CrossRef]

37. El Arabi, N. Environmental management of groundwater in Egypt via artificial recharge extending the practice to soil aquifer treatment (SAT). Int. J. Environ. Sustain. 2012, 1, 66-82. [CrossRef]

38. Tredoux, G.; Van Der Merwe, B.; Peters, I. Artificial recharge of the Windhoek aquifer, Namibia: Water quality considerations. Boletín Geológico Min. 2009, 120, 269-278.

39. DWA. Water Banking: A Practical Guide to Using Artificial Groundwater Recharge; Department of Water Affairs: Pretoria, South Africa, 2010.

40. Mohn, R.; Abdurahman, M.A.; Gardemann, J.; Mathys, W.; Nedaw, D.; Kruse, B.; Herbst, C. Subsurface Micro-Reservoirs for Rural Water Supply in the Ethiopian Highlands, v. Available online: https://www.hb.fhmuenster.de/opus/fhms/volltexte/2012/780/ (accessed on 26 October 2017).

41. Murray, R. Prince Albert Municipality. In Groundwater Management and Artificial Recharge Feasibility Study; Groundwater Africa: Cape Town, South Africa, 2007.

42. Murray, R. Bitou Municipality Groundwater Management and Artificial Recharge Feasibility Study; Groundwater Africa: Cape Town, South Africa, 2007.

43. Murray, E.; Tredoux, G. Pilot Artificial Recharge Schemes: Testing Sustainable Water Resource Development in Fractured Aquifers; Water Research Commission: Pretoria, South Africa, 2002. 
44. Zammouri, M.; Brini, N.; Horriche, F.J. Assessment of Artificial Recharge Efficiency against Groundwater Stress in the El Khairat Aquifer. In Groundwater and Global Change in the Western Mediterranean Area; Springer: Berlin/Heidelberg, Germany, 2018; pp. 305-312.

45. Bennani, A.; Lary, J.; Nrhira, A.; Razouki, L.; Bize, J.; Nivault, N. Wastewater treatment of greater Agadir (Morocco): An original solution for protecting the bay of Agadir by using the dune sands. Water Sci. Technol. 1992, 25, 239-245. [CrossRef]

46. Igboekwe, M.U.; Ruth, A. Groundwater recharge through infiltration process: A case study of Umudike, Southeastern Nigeria. J. Water Resour. Prot. 2011, 3, 295. [CrossRef]

47. Murray, R. Artificial Recharge Lecture Notes. In Artificial Recharge: The Intentional Banking and Treating of Water in Aquifers; Department of Water Affairs and Forestry: Pretoria, South Africa, 2008.

48. Dillon, P.J.; Pavelic, P. Guidelines on the Quality of Stormwater and Treated Wastewater for Injection into Aquifers for Storage and Reuse; Urban Water Research Association of Australia: Melbourne, Australia, 1996.

49. Prathapar, S.; Sharma, B.R.; Aggarwal, P.K. Hydro, Hydrogeological Constraints to Managed Aquifer Recharge in the Indo Gangetic Plains; International Water Management Institute: Colombo, Sirlanka, 2012.

50. Botha, F. Can Man-Made Aquifers Provide a Solution for a Thirsty Mining Industry? In Proceedings of the International Symposium on Managed Aquifer Recharge (ISMAR 7), Abu Dhabi, UAE, 9-13 October 2009.

51. DWA. Potential Artificial Recharge Areas in South Africa; PRSA 000/00/11609/1-Activity 14 (AR04); Department of Water Affairs: Pretoria, South Africa, 2009.

52. Tredoux, G.; Genthe, B.; Steyn, M.; Engelbrecht, J.; Wilsenach, J.; Jovanovic, N. An assessment of the Atlantis artificial recharge water supply scheme (Western Cape, South Africa). WIT Trans. Ecol. Environ. 2009, 127, 403-413.

53. Bouchaou, L. MAR techniques and examples successfully applied in light of climate change adaptation: Case study in Morocco. In Proceedings of the Conference Presentation-Theme Opportunities for Managed Aquifer Recharge, Amman, Jordan, 11-14 December 2012.

54. Bouragba, L. Etude de la recharge artificielle des nappes en zone semi-aride (Application au bassin du Souss-Maroc). In Study of Artificial Recharge of Groundwater in Semi-Arid Areas (Application to the Souss-Maroc basin), U.F.R Sciences \& Techniques; Université de Franche-Comté École Doctorale Homme, Environnement: Santé, France, 2011.

55. Choukr-Allah, R.; Ragab, R.; Bouchaou, L.; Barceló, D. The Souss-Massa River Basin, Morocco; Springer: Berlin/Heidelberg, Germany, 2017.

56. Al-Turbak, A.S. Effectiveness of recharge from a surface reservoir to an underlying unconfined aquifer. In Proceedings of the Vienna Symposium of the Hydrology of Natural and Manmade Lakes, Vienna, Austria, 11-24 August 1991; pp. 191-196.

57. Ghiglieri, G. WADIS-MAR Project: Water harvesting and Agricultural technique in Dry lands: An integrated and Sustainable model in MAghreb Regions. In Proceedings of the WADIS-MAR: Achievements, Activities, WADIS-MAR final Conference International Workshop on Sustainable water Resources Management in Arid and Semi-Arid Regions, Sassari, Italy, 16 June 2016.

58. DWA. Potential Artificial Recharge Schemes: Planning for Implementation; Department of Water Affairs: Pretoria, South Africa, 2010.

59. Mhamdi, R.; Heilweil, V. A Quantitative Evaluation of the Impacts of Artificial Recharge to the Mornag Aquifer System of Northern Tunisia; Acacia Publications: Phoenix, AZ, USA, 2007; pp. 484-493.

60. DWS. Water Outlook 2018 Report, Revision 25-Updated 20 May 2018 Produced by Department of Water and Sanitation (DWS) City of Cape Town; Department of Water and Sanitation: Cape Town, South Africa, 2018.

61. De Trincheria, J.; Nissen-Petersen, E.; Walter, L.F.; Otterphol, R. Factors affecting the performance and cost-efficiency of sand storage dams in South-Eastern Kenya. In Proceedings of the 36th IAHR World Congress, Hague, The Netherlands, 28 June-3 July 2015.

62. Borst, L.; De Haas, S. Hydrology of Sand Storage Dams: A Case Study in the Kiindu Catchment, Kitui District, Kenya; VU University Amsterdam: Amsterdam, The Netherlands, 2006.

63. El-Fakharany, Z. Environmental Impact Assessment of Artificial Recharge of Treated Wastewater on Groundwater Aquifer System Case study Abu-Rawash, Egypt. J. Am. Sci. 2013, 9, 309-315.

64. Botha, F.; Maleka, L. Results show that man-made aquifers within the platinum mining industry in South Africa can provide a solution for future water demands. In Proceedings of the International Mine Water Conference, Aachen, Germany, 4-11 September 2011. 
65. Page, D.; Dillon, P.; Vanderzalm, J.; Bekele, E.; Barry, K.; Miotlinski, K.; Levett, K. Managed Aquifer Recharge Case Study Risk Assessments; Water for a Healthy Country National Research Flagship Report Series ISSN: 1835-095X; CSIRO: Canberra, Australia, 2010.

66. NRMMC-EPHC-NHMRC. National Water Quality Management Strategy Document No 24. In Australian Guideline for Water Recycling Managing Health and Environmental Risks (Phase 2), Managed Aquifer Recharge Natural Resource; Biotext: Canberra, Australia, 2009.

67. RAIN. A Practical Guide to Sand Dam Implementation Water Supply through Local Structures as Adaptation to Climate Change; RAIN Foundation: Amsterdam, The Netherlands, 2008.

68. Demenge, J.; Alba, R.; Welle, K.; Manjur, K.; Addisu, A.; Mehta, L.; Woldearegay, K. Multifunctional roads: The potential effects of combined roads and water harvesting infrastructure on livelihoods and poverty in Ethiopia. J. Infrastruct. Dev. 2015, 7, 165-180. [CrossRef]

69. Puertas, D.G.-L.; Woldearegay, K.; Mehta, L.; Beusekom, M.; Agujetas, M.; Van Steenbergen, F. Roads for water: The unused potential. Waterlines 2014, 33, 120-138. [CrossRef]

70. Van Steenbergen, F.; Haile, A.M.; Alemehayu, T.; Alamirew, T.; Geleta, Y. Status and potential of spate irrigation in Ethiopia. Water Resour. Manag. 2011, 25, 1899-1913. [CrossRef]

71. Boers, T.M.; Ben-Asher, J. A review of rainwater harvesting. Agric. Water Manag. 1982, 5, 145-158. [CrossRef]

72. Helmreich, B.; Horn, H. Opportunities in rainwater harvesting. Desalination 2009, 248, 118-124. [CrossRef]

73. Pandey, D.N.; Gupta, A.K.; Anderson, D.M. Rainwater harvesting as an adaptation to climate change. Curr. Sci. 2003, 85, 46-59.

74. Woldearegay, K.; van Steenbergen, F.; Alemayehu, T.; Manjur, K.; Perez, M.A. The Beneficial Use of Road Water for Climate Resilience and Asset Management. In Proceedings of the 2nd IRF Africa Regional Congress, Windhoek, Namibia, 11-13 July 2017.

75. DWA. A Check-List for Implementing Successful Artificial Recharge Projects; PRSA 000/00/11609/2-Activity 12 (AR02); Department of Water Affairs: Pretoria, South Africa, 2009.

76. WorldPop (School of Geography and Environmental Science, University of Southampton; Department of Geography and Geosciences, University of Louisville; Departement de Geographie, Universite de Namur) and Center for International Earth Science Information Network (CIESIN), Columbia University (2018). Global High Resolution Population Denominators Project-Funded by The Bill and Melinda Gates Foundation (OPP1134076). 2020. Available online: https://dx.doi.org/10.5258/SOTON/WP00647 (accessed on 8 June 2020).

77. Martin, R. Clogging Issues Associated with Managed Aquifer Recharge Methods; IAH Commission on Managing Aquifer Recharge: Australia, 2013. Available online: https://recharge.iah.org/files/2015/03/Clogging Monograph.pdf (accessed on 8 June 2020).

78. Hanson, G.; Nilsson, Å. Ground-Water Dams for Rural-Water Supplies in Developing Countries. Groundwater 1986, 24, 497-506. [CrossRef]

79. Gale, I. Strategies for Managed Aquifer Recharge (MAR) in Semi-Arid Areas; UNESCO IHP: Paris, France, 2005.

80. Foster, S.; Tuinhof, A. Subsurface Dams to Augment Groundwater Storage in Basement Terrain for Human Subsistence-Brazilian and Kenyan Experience. World Bank Groundw. Manag. Advis. Team 2004, 5, 78-92.

81. Sobowale, A.; Ramalan, A.; Mudiare, O.; Oyebode, M. Groundwater recharge studies in irrigated lands in Nigeria: Implications for basin sustainability. Sustain. Water Qual. Ecol. 2014, 3, 124-132. [CrossRef]

82. Department of Water Affairs. Artificial Recharge Strategy Version 2; 2010 November. Available online: http://www.artificialrecharge.co.za/strategydocument/ARTIFICIAL_RECHARGE_STRATEGY_Ver_ 2_071210_update_010211_1.pdf (accessed on 8 June 2020).

83. Bachtouli, S.; Comte, J.-C. Regional-Scale Analysis of the Effect of Managed Aquifer Recharge on Saltwater Intrusion in Irrigated Coastal Aquifers: Long-Term Groundwater Observations and Model Simulations in NE Tunisia. J. Coast. Res. 2019, 35, 91-109.

84. Chaieb, H.; Moncef, R.; Ouerfelli, N.; Laghi, M.; Magagnini, L.; Tosatto, O.; De Angelis, A.; Sollazzo, F.; Teatini, P. On the effectiveness of reusing treated wastewater by infiltration ponds in coastal farmlands. Preliminary investigation on insights from the Korba site, Tunisia. In Proceedings of the 1st CIGR Inter-Regional Conference on Land and Water Challenges, Bari, Italy, 10-14 Septemebr 2013. 
85. Ouelhazi, H.; Lachaal, F.; Charef, A.; Challouf, B.; Chaieb, H.; Horriche, F.J. Hydrogeological investigation of groundwater artificial recharge by treated wastewater in semi-arid regions: Korba aquifer (Cap-Bon Tunisia). Arab. J. Geosci. 2014, 7, 4407-4421. [CrossRef]

86. Rekaya, M.; Bedmar, A.P. The Tunisian Experience in Ground Water Artificial Recharge by Treated Wastewater. In Proceedings of the Artificial Recharge of Ground Water, Anaheim, CA, USA, $23-27$ August 1988; pp. 612-627. 